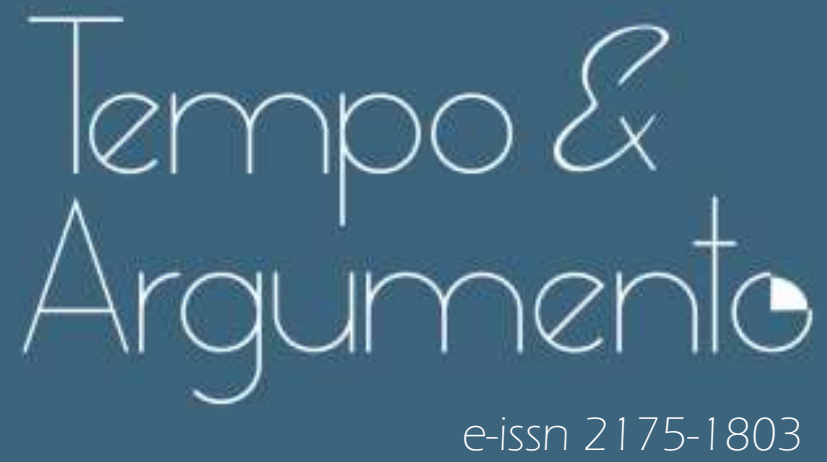

\title{
Políticas e poéticas de memória: olhares
}

e travessias

- Janice Gonçalves

Doutora em História pela Universidade de São Paulo (USP).

Professora do Programa de Pós-Graduação em História da Universidade do Estado de Santa Catarina (UDESC).

Florianópolis, SC - BRASIL

lattes.cnpq.br/1648801931749201

janice.gnclvs@gmail.com

(D) orcid.org/0000-0002-1791-3688

Para citar este artigo:

GONÇALVES, Janice. Políticas e poéticas de memória: olhares e travessias. Tempo

e Argumento, Florianópolis, e0 104, 2021. Número especial.

dol http://dx.doi.org/10.5965/21751803ne2021e0104 


\title{
Políticas e poéticas de memória: olhares e travessias
}

\begin{abstract}
Resumo
Com base em reflexões de autores como Andreas Huyssen, Maria Angélica Melendi, Paola Helena Acosta Sierra e Diana Taylor, são discutidas algumas formas de intervenção no espaço público que, contemporaneamente, operam com a memória (muito especialmente, a memória traumática) e lançam mão de formas expressivas ou atos performativos que, por sua vez, articulam poéticas e políticas. Examina-se, mais detidamente, o projeto "Re(vi)vendo Êxodos", experiência brasileira na área de educação que, inspirada em uma exposição fotográfica de Sebastião Salgado, tem proposto há 2 décadas percursos de formação criativos e renovadores, baseados em trabalhos de campo e, muito especialmente, em 2 atos performativos: fotografar e caminhar. Uma experiência que articula o performar e o formar, assim como a produção intensa de vetores de memória (como os registros documentais fotográficos) em associação com dimensões incorporadas (coletivas e individuais) da memória.
\end{abstract}

Palavras-chave: memória; fotografia; caminhada; Sebastião Salgado; educação.

\section{Memory policies and poetics: views and passages}

\begin{abstract}
Based on reflections by authors like Andreas Huyssen, Maria Angélica Melendi, Paola Helena Acosta Sierra, and Diana Taylor, this article discusses some modes of intervention in the public space that, contemporarily, deal with memory (quite especially, traumatic memory) and resort to expressive effects or performative acts that, in turn, interconnect poetics and policies. The project "Reviving/Reviewing Migrations" is examined in detail, a Brazilian experience in the education area that, inspired by a photographic exhibition by Sebastião Salgado, has been proposing for 2 decades creative and renovating qualification paths, based on fieldwork and, quite especially, on 2 performative acts: photographing and hiking. An experience that interconnects performing and educating, as well as the intense production of memory vectors (such as photographic documentary records) in association with incorporated (collective and individual) memory dimensions.
\end{abstract}

Keywords: memory; photography; hiking; Sebastião Salgado; education. 


\section{Introdução}

[...] um acontecimento vivido é finito, ou pelo menos encerrado na esfera do vivido, ao passo que o acontecimento lembrado é sem limites, porque é apenas uma chave para tudo o que veio antes e depois (BENJAMIN, 1985, p. 37).

Poética e política são palavras com origem grega e sua etimologia indica, para a primeira, os sentidos de criação, invenção e fabricação (tendo poíesis como referência) e, para a segunda, o agir no espaço público, consideradas as diretrizes e normas pelas quais deve se pautar (ou se propõe que se paute) uma dada coletividade (a palavra grega de referência, neste caso, é politeía, remetendo à polis)'. Embora as acepções dessas duas palavras tenham se ampliado nas trajetórias históricas de seus usos, essas chaves primordiais de sentido fornecem quadros norteadores para as questões que pretendo aqui abordar. Tomo como horizonte dimensões da memória que vêm sendo ou podem ser articuladas no espaço público, com ênfase em formas criativas, inventivas, imaginativas, expressivas - poéticas, enfim - de fazê-lo.

A esse respeito, a produção acadêmica tem se debruçado com certa intensidade sobre obras e performances de caráter artístico que remetem a memórias de experiências contemporâneas traumáticas.

Andreas Huyssen (2014b) pôs em relevo os artistas visuais Nalini Malani e William Kentridge, em especial trabalhos que, lidando com elementos do teatro de sombras, tematizaram problemas e traumas associados à divisão da Índia, a partir da independência (Malani), ou ao apartheid, na África do Sul (Kentridge). Huyssen (2014a) discutiu, ainda, aspectos dos projetos memoriais que resultaram no "Monumento aos judeus assassinados da Europa" (elaborado pelo arquiteto Peter Eisenman e construído em Berlim) e no Memorial ao 11 de setembro, em

\footnotetext{
No que se refere ao contexto da Grécia clássica, a ação por si só seria praxis, sendo que a ação na esfera pública especificamente, de modo a resultar na política, envolveria, sobretudo, o uso da palavra (o discurso ou lexis), para argumentar e persuadir (a respeito, ver ARENDT, Hannah. A condição humana. Rio de Janeiro: Forense Universitária, Salamandra; São Paulo: Edusp, 1981. p. 31-37). Na apresentação da Política de Aristóteles, traduzida para o português por Mário da Gama Kury, o tradutor destacou que a concepção aristotélica dos diferentes campos de conhecimento traçou uma divisão entre as ciências teóricas (como a metafísica e a teologia) e as práticas. Entre as práticas, por sua vez, poderiam ser diferenciadas aquelas "que nos ensinam a produzir coisas" ("ciências "poiéticas"”) e aquelas "que nos mostram como agir" (com relevo dado à política, "ciência do bem-estar e da felicidade dos homens como um todo") (KURY, 1997, p. 7-8).
} 
Nova York (projetado pelos arquitetos Michael Arad e Peter Walker, ao qual foi integrado um museu)2.

Maria Angélica Melendi (2006) tratou de algumas iniciativas na Argentina, como a escultura de Yaacov Agam e o monumento erguido pelo grupo Memoria Activa, alusivos ao atentado que em julho de 1994 destruiu a sede da Asociación Mutual Israelita Argentina, em Buenos Aires. O grupo Memoria Activa, formado por amigos e familiares das 85 vítimas daquele atentado (EL ATAQUE, 2004), ao longo de uma década se dirigiu semanalmente à Plaza Lavalle, às segundasfeiras, no horário em que explodiu a bomba, para promover junto ao monumento um minuto de silêncio, "como expressão de homenagem, recordação e exigência de justiça” (MELENDI, 2006, p. 234). Melendi também refletiu sobre o "Monumento a las víctimas del terrorismo de Estado" e o "Parque de la Memoria", instalados na Avenida Costanera Rafael Obligado, em Buenos Aires, que se referem a ações repressivas - envolvendo sequestros, aprisionamentos, torturas e assassinatos - consumadas na Argentina entre 1969 e 1983 (MELENDI, 2006, p. 238-244; PARQUE, 2021). A autora ainda contrapôs essa última perspectiva “monumental" às publicações cotidianas, no jornal argentino Página 12, de fotos de desaparecidos políticos. Acompanhadas de breves textos biográficos, para a autora tais publicações seriam similares a "lápides de papel”. E indagou:

Onde, finalmente, localizar a memória? Lá longe, no Parque, nas bordas da cidade e na margem do rio, num espaço longínquo que se afasta do fluir da vida? Ou no cotidiano da página do jornal, à hora do café da manhã, como o momento obrigatório de reflexão e meditação, que nos faça ver e lembrar dia após dia, rosto após rosto, para evitar o olvido oficial, a amnésia social que está implícita na ideia de monumento? (MELENDI, 2006, p. 245).

Para além do distanciamento entrevisto por Maria Angélica Melendi em monumentos que, embora erguidos em espaços públicos, ficariam afastados do "fluir da vida", as performances, mesmo que não sejam renovadas "dia após dia”,

\footnotetext{
Os museus dedicados a memórias traumáticas têm sido objeto de estudo de vários pesquisadores, entre eles a socióloga Amy Sodaro (2018), que propôs a categoria "memoriais" para as instituições museais voltadas prioritariamente para a abordagem de passados marcados pela violência e pelos sofrimentos dela decorrentes. Em seu livro sobre o tema, Sodaro se voltou mais detidamente para as seguintes instituições: Museu Memorial do Holocausto, em Washington D.C., EUA; Casa do Terror, em Budapeste, Hungria; Centro Memorial do Genocídio de Quigali, em Ruanda; Museu da Memória e dos Direitos Humanos, em Santiago, Chile; Museu Memorial do 11 de Setembro, em Nova Iorque, EUA. Há tradução para o português da introdução do livro (SODARO, 2019).
} 
têm sido delineadas como canais poéticos com maior potencial de alcance - aí incluídas desde apresentações teatrais a intervenções pontuais e variadas no ambiente urbano.

Paola Helena Acosta Sierra (2019) analisou obras da dramaturgia que tratam de tensões e violências indeléveis na história política recente da Colômbia, como as peças teatrais "Río arriba, río abajo: Antígona en el puente cantando", "Donde se descomponen las colas de los burros" e "Arimbato, el camino del árbol", de autoria, respectivamente, de Jesús Domínguez, Carolina Vivas e Felipe Vergara. A autora considerou que essas "dramaturgias do conflito" cumprem um papel relevante para rever e ampliar as políticas públicas de memória, uma vez que remetem a memórias não hegemônicas, permitindo repensar os elementos do passado traumático engastados no presente. Trata-se, ainda, de abordar memórias dos cidadãos que sofreram diretamente ações violentas deflagradas em decorrência dos embates entre instâncias do Estado e a guerrilha, de modo a colaborar para garantir direitos às vítimas (ACOSTA SIERRA, 2019, p. 314).

Uma dramaturgia que versa sobre os traumas da história contemporânea peruana foi, por sua vez, alvo das reflexões de Diana Taylor (2013, p. 263-293), ao abordar a trajetória da cooperativa de teatro Yuyachkani, principalmente da montagem e das apresentações das peças "Contraelviento" e "Adiós Ayacucho". Taylor também refletiu sobre os "escraches" e outras intervenções no espaço público de Buenos Aires, promovidas pela organização H.I.J.O.S. (integrada por filhos de desaparecidos), em articulação com o Grupo de Arte Callejero; tais intervenções focalizaram as ações de repressão da ditadura argentina, entre os anos 1970 e 1980, assim como as memórias das vítimas (TAYLOR, 2013, p. 229262).

Para Diana Taylor, há atos performativos que permitem alcançar e afetar as pessoas, de modo a transformá-las em "testemunhas". Com referência ao Yuyachkani, afirmou:

O Yuyachkani, como seu nome indica ${ }^{3}$, depende da noção de interconexão: o "eu" que pensa/lembra é inextricável do "você" cujo pensamento "eu" sou. O eu/você do Yuyachkani promete ser

\footnotetext{
${ }^{3}$ Com base em Hugo Salazar de Alcázar, Taylor ressalta que Yuyachkani significa, em quéchua, "estou pensando" / "estou lembrando" /"eu sou seu pensamento" (TAYLOR, 2013, p. 264).
} 
uma testemunha, um fiador da ligação entre o "eu" e o "você", o "dentro" e o "fora". O Yuyachkani torna-se a testemunha tardia do drama contínuo e não reconhecido da atrocidade e convida seu público a fazer o mesmo. [...] a representação, para o Yuyachkani, não contribui para aumentar a dessacralização das vítimas, transformando sua dor em fonte de prazer para os espectadores. Em vez disso, sem a representação, os espectadores não reconheceriam seu papel na história contínua de opressão que, direta ou indiretamente, envolve a todos. (TAYLOR, 2013, p. 292).

A partir do caso do coletivo teatral peruano, Diana Taylor propõe refletir sobre uma espécie de testemunho de segundo grau, já que o testemunhado diria respeito à representação de algo vivido e/ou presenciado por outrem; representação fundamentada, por sua vez, nas memórias das vivências em questão. Sem aprofundar aqui a discussão quanto à pertinência de compreender a ação de testemunhar como transferível, conforme Taylor ${ }^{4}$, entendo que suas considerações são instigantes por apontarem para algumas condições favoráveis à transmissão de memórias: uma performance teatral (como as realizadas pelo grupo Yuyachkani) pode vir a ser o momento-chave em que alguém se conecta com o transmitido e, uma vez afetado por ele, passa igualmente a se comprometer com a transmissão dessa memória, tornando-se elo de uma ampla cadeia. O vivido pertence a quem o viveu (ou, como afirmou Benjamin, no comentário adotado como epígrafe, está "encerrado na esfera do vivido"); contudo, a memória do vivido pode ser partilhada (tornando infinito o finito, na perspectiva benjaminiana) ${ }^{5}$.

Os exemplos anteriormente citados indicam o campo fértil dos estudos dedicados a pensar as interações entre políticas de memória (hegemônicas ou não) e expressões artísticas ou atos performativos, quer mobilizem agentes institucionais do campo das artes e do campo patrimonial, quer enfoquem e

\footnotetext{
4 "O ato de testemunhar é transferível; assim, o teatro, como o testemunho, a fotografia, o filme ou o relato, pode transformar outros em testemunhas” (TAYLOR, 2013, p. 292). Portanto, na perspectiva da autora, não apenas performances, mas ainda seus resultados concretos (como registros fotográficos e filmes) poderiam ser vetores de transferência. Taylor afirmou algo semelhante (mas remetendo à transmissão da experiência traumática) em texto sobre o H.I.J.O.S.: "a transmissão da experiência traumática se parece mais com o 'contágio' - uma pessoa 'pega' e incorpora o peso, a dor e a responsabilidade de comportamentos/acontecimentos passados. A experiência traumática pode ser transmissível, mas é inseparável do sujeito que a sofre" (TAYLOR, 2013, p. 236).

5 Especificamente quanto às possibilidades de uma memória traumática afetar alguém distante da experiência que a gerou, as contribuições de Diana Taylor para esse debate, em articulação com as de Stephen Greenblatt, foram exploradas em outro texto (GONÇALVES, 2018).
} 
projetem práticas vinculadas à ação (individual ou coletiva) de cidadãos sem vínculos com tais campos.

Neste artigo, contudo, não me detenho nas experiências traumáticas contemporâneas sob o crivo de obras de caráter artístico, performances e intervenções urbanas inventivas, ou mesmo projetos memoriais traduzidos em monumentos e museus. Em um tempo de sombras e asperezas como o que vivemos, optei por destacar uma proposta pedagógica que, apoiada em reflexões e registros sobre experiências traumáticas de deslocamentos populacionais (na sensível poética fotográfica de Sebastião Salgado), os ressignificou, transfigurando dor em esperança. Trata-se de uma ação pedagógica brasileira com 20 anos de existência, reconhecida na área educacional e na do patrimônio cultural (inclusive premiada): o projeto "Re(vi)vendo Êxodos" ${ }^{6}$. Nascido em uma escola pública de Brasília, o projeto tem engajado, antes de tudo, docentes e discentes, mas sabendo estabelecer parcerias com profissionais e diversas instituições públicas e entidades, em diferentes níveis. Articulou com força 2 atos performativos: o ato de fotografar e o de caminhar. Uma experiência que permanece aberta, em processo, na qual têm se combinado invenção e intervenção, ação e reflexão, memória e história.

\section{Fotografar}

Conforme ressaltado mais de uma vez por um de seus idealizadores e, posteriormente, coordenador geral, o projeto "Re(vi)vendo Êxodos" foi inspirado pela visitação que grande parte das escolas do Distrito Federal (muitas delas públicas) realizou, em 2001, à exposição fotográfica sobre o projeto “Êxodos”, de Sebastião Salgado, à qual também está associado um livro. O Centro de Ensino Médio Setor Leste levou 20 turmas para conhecer a exposição - cerca de 700 alunos (BAPTISTA, 2009, p. 174; BAPTISTA, 2017, p. 50).

\footnotetext{
6 O projeto recebeu menção honrosa no IV Prêmio José Aparecido de Oliveira, em 2011 (RE(VI)VENDO, 2011) e 1o lugar na edição seguinte do mesmo prêmio (A SECRETARIA, 2012). Foi premiado na categoria "Iniciativas de excelência em promoção e gestão compartilhada do Patrimônio Cultural”, na 28ạ. edição do Prêmio Rodrigo Melo Franco de Andrade/Iphan, em 2015 (IPHAN, 2015). Além disso, o Centro de Ensino Médio Setor Leste foi uma das escolas contempladas, em 2012, no Prêmio Gestão Escolar, do Conselho Nacional de Secretários de Educação (indicada como uma das escolas "destaques nacionais"), tendo salientado o projeto "Re(vi)vendo Êxodos” entre suas ações (QUAL, 2012).
} 
Por sua vez, a exposição do projeto "Êxodos", bem como o livro (SALGADO, 2000), resultaram de viagens realizadas pelo fotógrafo brasileiro por mais de 40 países, durante 6 anos, acompanhando longos deslocamentos de grupos humanos (e algumas de suas consequências). Deslocamentos geralmente provocados por situações dolorosas: guerras, perseguições, conflitos por terra, doenças, pobreza, fome... O trabalho fotográfico de Salgado foi inspirado por esses percursos, muitos deles realizados a pé, por pequenos grupos ou por multidões, que tentaram superar o ódio, o sofrimento, a injustiça e a morte, servindo-se de acomodações precárias em meio ao caminho ou no ponto de chegada (mesmo que fosse a chegada possível, distante da desejada, como no caso dos campos de refugiados).

Mas por que testemunhar e documentar tudo isso, fazendo uso da fotografia?

Em livro sobre sua trajetória pessoal, escrito em conjunto com a jornalista Isabelle Francq quase 20 anos após o início do projeto "Êxodos", Salgado declarou suas intenções:

Nos quatro cantos do globo, as pessoas são deslocadas essencialmente pelas mesmas razões econômicas, que favorecem uma minoria, enquanto a maioria se torna miserável. E em toda parte a superpopulação resultante amplia os mesmos males: precariedade, violência, epidemias... Às vésperas do terceiro milênio, eu quis mostrar essas pessoas em trânsito, sua coragem diante do desenraizamento, sua incrível capacidade de adaptação a situações em geral muito difíceis. Eu quis mostrar que, cada um à sua maneira, todos manifestam no mundo seu espírito de iniciativa e a riqueza de suas diferenças. Às vésperas do século XXI, tentei mostrar a necessidade de refundarmos a família humana sobre as bases da solidariedade e da partilha (SALGADO; FRANCQ, 2014, p. 61-62).

Afirmam-se, assim, as positividades que podem ser vislumbradas nos sujeitos que se deslocam, estritamente migrantes ou refugiados, ao lado da necessidade de buscar alternativas para interromper a reprodução dos sofrimentos e injustiças (para refundar a "família humana", com base na solidariedade e na partilha). Essas duas perspectivas fundamentais já haviam sido apresentadas por Sebastião Salgado em conversa com John Berger, em 2001: à época, afirmou que quisera mostrar o intolerável das situações registradas por 
ele, de modo a provocar mudanças; ao mesmo tempo, enfatizar a dignidade e o valor de cada uma daquelas vidas em trânsito.

[...] tudo que têm com eles é só uma pequena fatia de esperança. E é com essa esperança que estão tentando conseguir outra posição estável na vida.

Se quem olhar essas fotos sentir compaixão, vou achar que falhei completamente. Quero que as pessoas entendam que podemos ter uma solução (SALGADO, 2017 apud BERGER, 2017b, p. 210).

O livro e a exposição, porém, não tiveram recepção unanimemente favorável. Na França, logo de início, sofreram duras críticas; o filósofo e historiador da arte Jean Galard destacou as de Michel Guerrin, que acusou o fotógrafo de aderir a um estetismo anestesiador quanto às difíceis situações exibidas, não obstante as pretensões de denúncia de Salgado (GALARD, 2012, p. 29). No livro Diante da dor dos outros, algumas dessas críticas foram comentadas por Susan Sontag, em parte relativizadas, em parte ampliadas: Salgado foi por ela caracterizado como "fotógrafo especializado na desgraça mundial", com livros e exposições ornamentados por uma "retórica santarrona", que em "Êxodos" teria enfocado "os destituídos de poder" de modo a reduzi-los "à impotência”. Seriam meros rostos sem nome (Sontag critica Salgado por não tê-los identificado), cujos infortúnios singulares terminariam por se dissolver em sofrimentos globais, "demasiado vastos, demasiado irrevogáveis, demasiado épicos" para provocar "qualquer medida política local". Nestes termos, considerou que "a compaixão pode apenas debater-se no vazio - e tornar-se abstrata" (SONTAG, 2003, p. 67$68)^{7}$.

A beleza das imagens anularia o horror exibido e, consequentemente, o potencial de mobilização? Para Jean Galard,

[...] a questão é saber se a disposição estética (a percepção da beleza em regiões onde não se esperava encontrá-la) é mobilizadora ou estéril, se propicia um acesso ativo à compreensão da realidade ou se ela destitui de realidade todas as coisas até chegar à anestesia (GALARD, 2012, p. 30).

\footnotetext{
Contudo, como visto anteriormente, em trecho de entrevista concedida por Salgado a John Berger, o fotógrafo declarou não ter buscado gerar compaixão naqueles que tomassem contato com seu trabalho - ao contrário, entendia que isso denotaria um fracasso, uma falha.
} 
E, aludindo às imagens fotográficas produzidas por Salgado, o autor francês acrescentou: "ele as faz para nos forçar a olhá-las; se, além disso, forem belas, terão alguma possibilidade de ser lembradas mais intensamente" (GALARD, 2012, p. 126).

Esse debate, repleto de ciladas, encontrou respostas e desdobramentos inesperados e criativos no projeto "Re(vi)vendo Êxodos".

Após as visitas de turmas de discentes do Centro de Ensino Médio Setor Leste à exposição fotográfica "Êxodos", um grupo de professores da área de Ciências Humanas dessa escola pública do Distrito Federal, tendo à frente o professor de História Luís Guilherme Baptista, propôs a alunos e alunas algo inspirado no projeto de Sebastião Salgado: que se voltassem para realidades e vivências presentes em Brasília, ou em cidades próximas, e refletissem sobre os paralelos possíveis com o que havia sido registrado pelo fotógrafo, em vários países. Nasceu, assim, o projeto "Re(vi)vendo Êxodos". Em um primeiro momento, como recordou, em 2017, o professor Luís Guilherme,

[...] os alunos foram instruídos a estudar e pesquisar aspectos históricos, geográficos, filosóficos e sociológicos que perpassavam pelos temas e assuntos abordados nas incríveis imagens que Salgado nos proporcionou. E o resultado ficou bom. Apresentaram seminários e trabalhos escritos. Ficou muito bom. Nós professores ainda não estávamos satisfeitos, então alguém sugeriu que fizéssemos os alunos tirarem fotografias dos mesmos temas trabalhados por Sebastião Salgado. Foi incrível. [...] nós decidimos que eles deveriam 'olhar' e achar todos os temas dentro das fronteiras do DF (BAPTISTA, 2017, p. 50).

Os registros fotográficos, informados por esses distintos olhares, foram exibidos em uma exposição, inaugurada em 6 de agosto de 2001, com curadoria da fotógrafa Mila Petrillo, que se tornou colaboradora do projeto. A exposição aconteceu fora da escola, no Espaço Cultural Renato Russo: caberia fazer com que os alunos-fotógrafos partilhassem suas visões com outros moradores da capital e vizinhanças, não restringindo o alcance dessa ação educativa ao ambiente escolar. O mesmo local sediou outras exposições, como a de 2017, cuja inauguração aparece registrada nas imagens 1, 2 e 3. 
Imagem 1 - Abertura da "Exposição Fotográfica dos Alunos do Centro de Ensino Médio Setor Leste”, dezembro de 2017, no Espaço Cultural Renato Russo, 508 Sul, Brasília, DF. Fala do coordenador geral do projeto "Re(vi)vendo Êxodos", Luís Guilherme Baptista, ao público. Foto de autoria de Wanessa Landim.

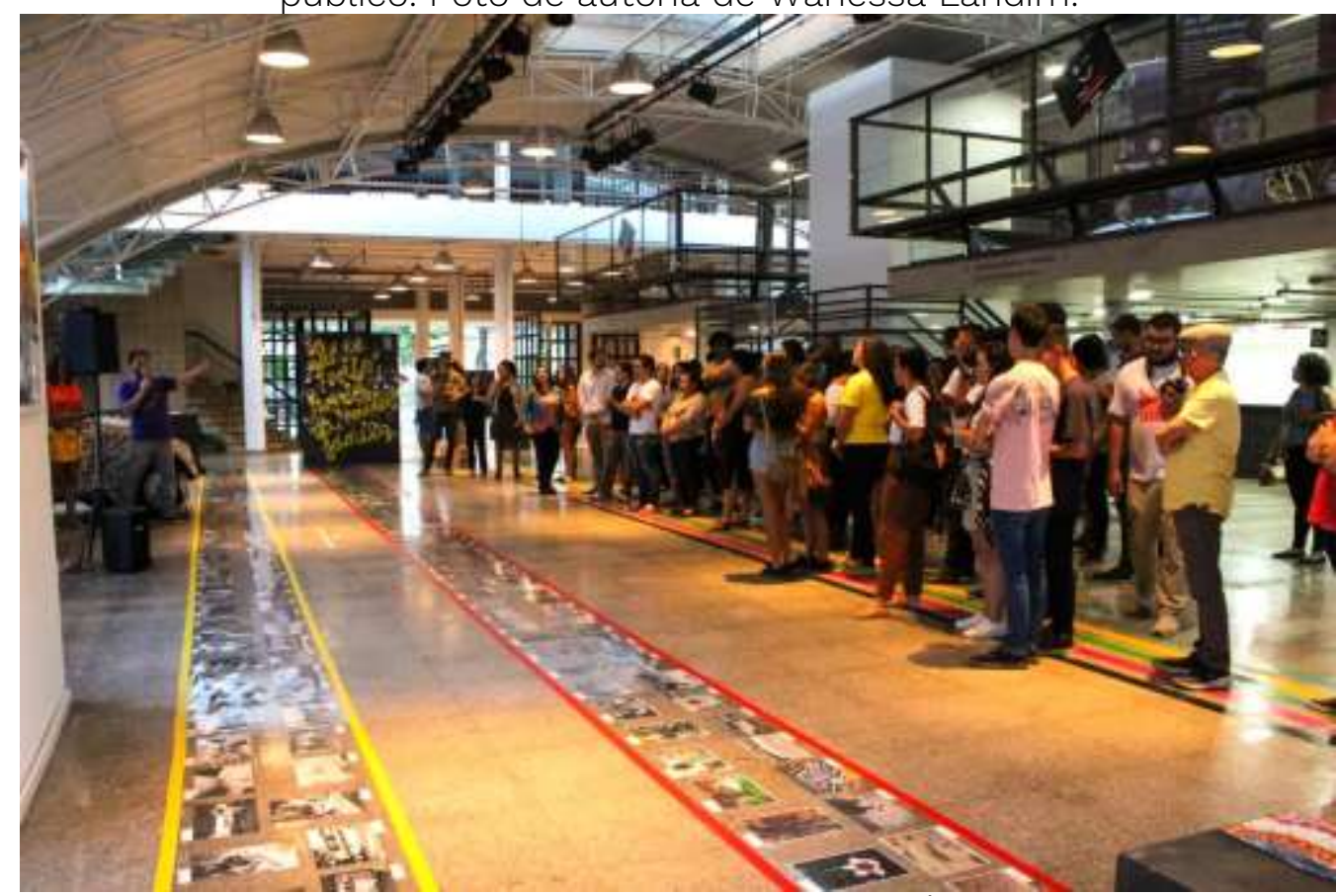

Fonte: acervo do projeto "Re(vi)vendo Êxodos".

Imagem 2 - Abertura da "Exposição Fotográfica dos Alunos do Centro de Ensino Médio Setor Leste”, dezembro de 2017, no Espaço Cultural Renato Russo, 508 Sul, Brasília, DF.

Para interagir com a exposição (inclusive fotografando-a), o público teve que mirar o chão a ser palmilhado, no qual foram afixadas as imagens fotográficas, todas em preto e branco. Foto de autoria de Wanessa Landim.

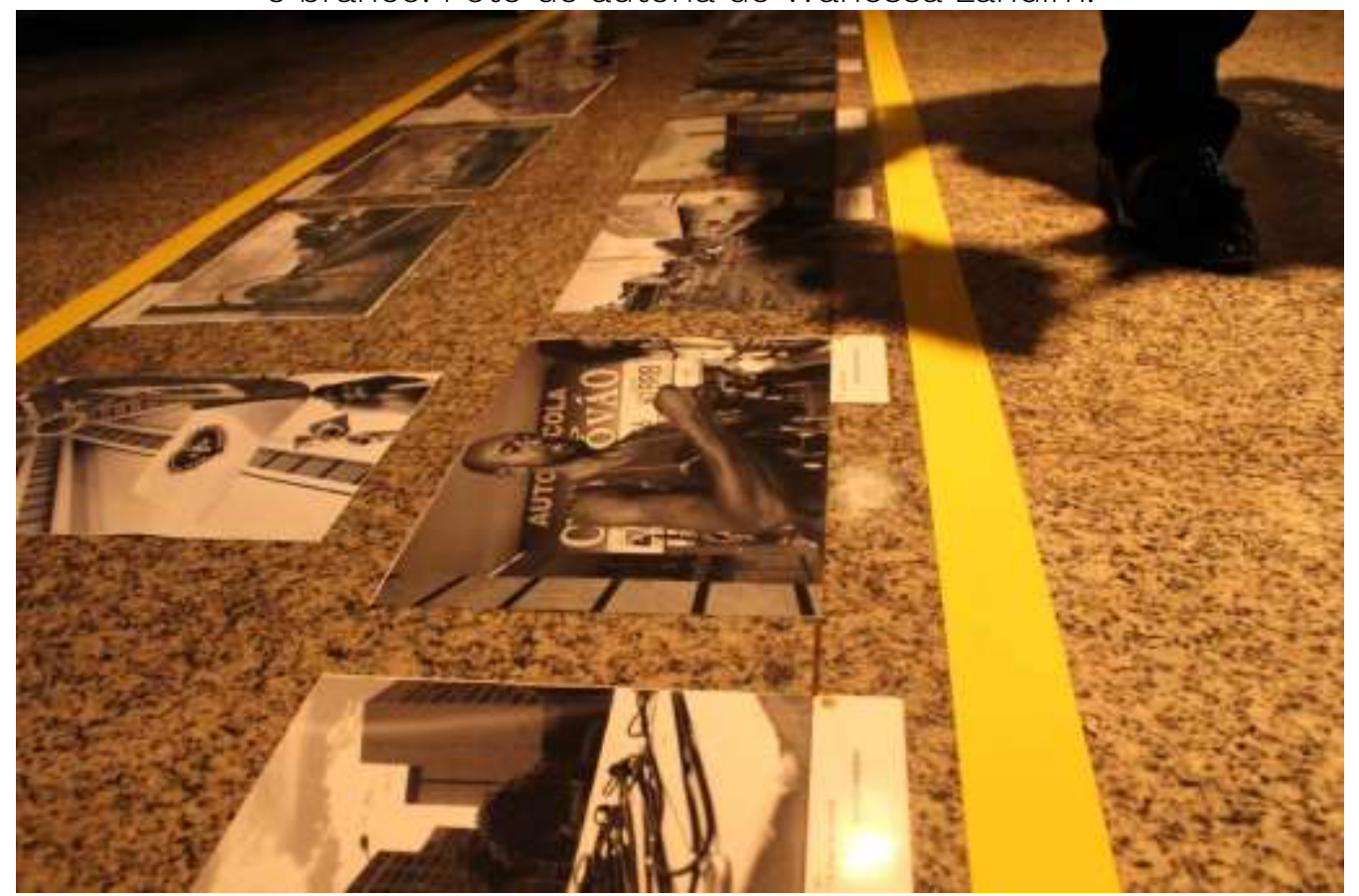

Fonte: acervo do projeto "Re(vi)vendo Êxodos". 
Imagem 3 - Abertura da "Exposição Fotográfica dos Alunos do Centro de Ensino Médio Setor Leste", dezembro de 2017, no Espaço Cultural Renato Russo, 508 Sul, Brasília, DF. Para vários visitantes, não bastou caminhar ao longo das faixas amarelas e vermelhas que circunscreviam as imagens da exposição: ver mais de perto exigiu dobrar o corpo, aproximar-se do chão e, quando possível, lançar mão de celulares que permitissem ampliar a imagem ou reproduzi-la. Foto de autoria de Wanessa Landim.

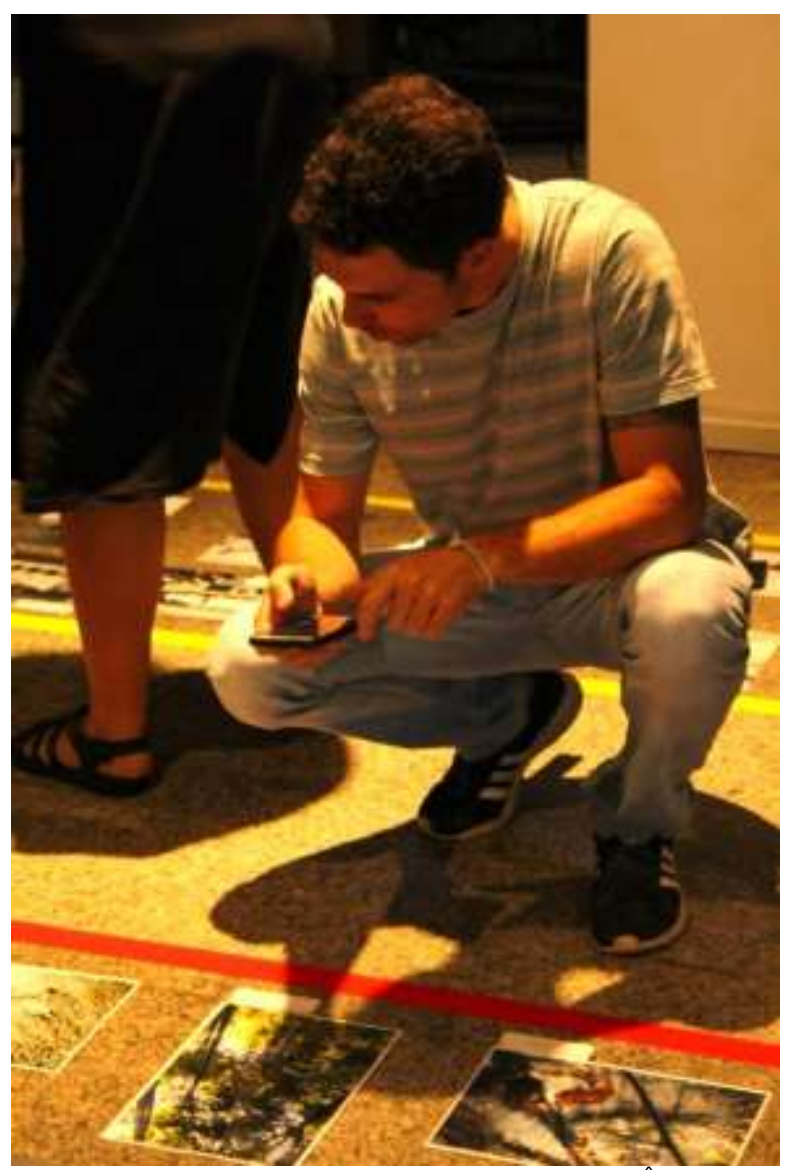

Fonte: acervo do projeto "Re(vi)vendo Êxodos".

Renovada anualmente, a exposição fotográfica firmou-se como uma das atividades básicas do projeto. Abrindo-se a novos temas e perspectivas, manteve-se como uma espécie de síntese e, simultaneamente, sementeira de percursos de pesquisa e descoberta (BAPTISTA, 2017; BAPTISTA, 2018) ${ }^{8}$.

\footnotetext{
${ }^{8}$ A exposição mais recente ocorreu em fevereiro de 2020, no Museu do Divino, em Pirenópolis, Goiás (VILLARREAL, 2020). As fotografias produzidas pelos discentes integram o acervo do projeto "Re(vi)vendo Êxodos" e podem ser conhecidas em parte com a consulta às edições da Revista Caminhos - o melhor do Brasil (https://www.revistacaminhos.org/ e https://issuu.com/revistacaminhos/L. Para este artigo, foi autorizada a publicação das 9 imagens nele contidas, de autoria de 3 ex-alunos que atualmente participam do projeto como monitores: Fontenelle Moraes, Rodrigo Soares e Wanessa Landim. Agradeço ao Prof. Luís Guilherme Baptista, coordenador geral do "Re(vi)vendo Êxodos", por me dar acesso ao material fotográfico do projeto, fornecer as informações de contextualização das imagens selecionadas e permitir seu uso neste texto.
} 
No projeto de Sebastião Salgado, a fotografia operou como meio para documentar acontecimentos tomados como índices de processos econômicos e sociais mais amplos, em especial os problemas e traumas por eles gerados, visibilizados fortemente em milhares de vidas errantes. Os termos documentar e documento, como sabemos, vêm do latim docere, verbo que se traduz por ensinar (LE GOFF, 1996, p. 536). Na base do ato de fotografar - se dermos crédito às intencionalidades afirmadas por Salgado - esteve a vontade de que os registros fotográficos produzidos no projeto "Êxodos" não apenas mostrassem, mas ensinassem sobre o registrado, convidando à reflexão e à mudança. Simultaneamente, se desenhou, neste ato, uma intenção de memória, articulada à percepção da intensa fragilidade daquelas vidas. No livro Êxodos, o fotógrafo assinalou:

[...] poucas pessoas abandonam a terra natal por vontade própria. [...] Partem com os pertences que conseguem carregar, avançam como podem a bordo de frágeis embarcações, espremidas em trens e caminhões, a pé... Viajam sozinhas, com as famílias ou em grupos. Algumas sabem para onde estão indo, confiantes de que as espera uma vida melhor. Outras estão simplesmente em fuga, aliviadas por estarem vivas. Muitas não conseguirão chegar a lugar nenhum (SALGADO, 2000, p. 9).

Sebastião Salgado tencionou, de um lado, ampliar a inscrição temporal dessas vidas particularmente frágeis por meio de registros fotográficos que, sendo fragmentos de seus dramas, poderiam funcionar como vetores de memória. Por outro lado, realizou um segundo gesto de inscrição memorial, referente à própria experiência por ele vivida no desenrolar do projeto, que envolveu convívio estreito e relativamente longo com os grupos fotografados ${ }^{9}$. Esses dois gestos memoriais são inseparáveis do ato fotográfico, que afirma, por meio do registro que dele resulta, um "isso aconteceu”, assim como, da parte do fotógrafo, um “assim vi o que aconteceu” (e, portanto, "eu estava lá”). Como comentou John Berger, em texto de 1968 no qual refletiu sobre os significados de uma fotografia:

\footnotetext{
Pôde também ativar memórias acerca de sua experiência de migração, como destacado por Paulo Maia (2017, p. 196): "há um percurso realizado, um tempo vivido e, sobretudo, memórias atravessadas no processo de construção de suas narrativas fotográficas. Memórias de um narrador viajante e, de certa forma, também migrante, já que ele mesmo se autoexilara do Brasil depois do golpe militar em 1964".
} 
A fotografia já é uma mensagem sobre o acontecimento que ela registra. [...] em seu sentido mais simples, a mensagem, decodificada, quer dizer: Eu decidi que a visão disso vale a pena ser registrada. [...] a fotografia é o processo de tornar a observação consciente de si mesma (BERGER, 2017a, p. 38, grifo do autor).

Esses elementos que afirmam a ação de documentar e, simultaneamente, o testemunho (e a interpretação) por parte de quem fotografa, estão presentes, portanto, nas imagens que compuseram, ano a ano, as exposições fotográficas do projeto "Re(vi)vendo Êxodos". Uma interessante amostragem está contida, aliás, em publicação on-line datada de 2014, produzida por três discentes da área de Design do Instituto de Educação Superior de Brasília (IESB) - Fernanda Alves, Gabriel Pereira e Luérison Alves -, sob a orientação do Prof. Bruno Porto. Na publicação foram reunidas imagens em preto e branco que apontam o interesse dos discentes participantes do "Re(vi)vendo Êxodos" pela arquitetura do espaço citadino, em especial seus arranjos provisórios, suas interações em peculiares composições geométricas, suas releituras por meio da sobreposição de objetos, inscrições e grafites; imagens que indicam a atenção dada aos ritmos e à dramaticidade da natureza, vislumbrados na configuração de árvores e de nuvens, assim como em flores e animais; informam sobre o incômodo com a degradação ambiental e com o sofrimento dos sem-teto ou daqueles que vivem em habitações precárias, ao mesmo tempo em que apresentam momentos de protesto e luta por melhores condições de vida. Uma seleção que demonstra a construção de olhares críticos acerca das realidades sociais fotografadas e, simultaneamente, a exploração das potencialidades da fotografia, com sensibilidade quanto a enquadramento, composição, uso da luz e efeitos de contraste (a respeito, ver ALVES, PEREIRA e ALVES, 20140).

Ao longo da existência do projeto, o material fotográfico foi articulado a intenso esforço de análise e reflexão. Mas a perspectiva formativa/educativa do "Re(vi)vendo Êxodos" necessariamente fez com que o projeto estivesse atento ainda a quem fotografava - e, com isso, que fossem interrogadas as pistas oferecidas pelas imagens fotográficas quanto aos significados dessa experiência

\footnotetext{
10 ALVES, Fernanda; PEREIRA, Gabriel; ALVES, Luérison. Re[vi]vendo Exxodos [fotografias do projeto]. Brasília: [Curso de Design, IESB], 2014. Disponível em: https://issuu.com/luerisonmiguelao/docs/revivendo__xodos_portfolio. Acesso em: 14 mar. 2021.
} 
para quem dela participara. A abertura enfática para processos criativos de produção de conhecimento deu grande visibilidade ao seu poder transformador: a partir das imagens produzidas (assim como de outros materiais, como textos e seminários de estudos), foi possível rastrear algo não apenas apreendido (captado momentaneamente), mas aprendido, apropriado de forma significativa.

O professor Luís Guilherme Baptista, referência-chave do "Re(vi)vendo Exxodos", em evento promovido pelo Instituto do Patrimônio Histórico e Artístico Nacional (Iphan), em 2009, ressaltou o quanto o projeto pretendia ser instrumento de formação de cidadãos críticos. E acrescentou:

[...] 75\% do meu público são da periferia e são alunos maravilhosos, geniais, inteligentes, criativos e lindos. Mas eles precisam de canais para se expressar. É fundamental, então, abrir esses processos, esses canais para eles poderem criar. Por isso, fizemos o projeto (BAPTISTA, 2012, p. 175).

Na trilha da abertura de canais criativos, o projeto "Re(vi)vendo Éxodos" promoveu o reencontro com elementos que também estavam presentes na empreitada de Sebastião Salgado, reconfigurando-os: a partir de 2004, o ato de caminhar - e caminhar longamente - foi incorporado como uma de suas atividades fundamentais.

\section{Caminhar}

No fotolivro "Êxodos” (e na exposição relacionada ao projeto homônimo), as longas caminhadas estavam geralmente marcadas, de diferentes maneiras, pela privação, o que reforçava os sofrimentos da "humanidade em trânsito", na expressão de Sebastião Salgado. Extensas, extenuantes e às vezes fatais, com frequência essas caminhadas se apresentaram, para aqueles que as realizaram, como a única alternativa diante de condições de vida que não podiam mais suportar. Já a incorporação de longas caminhadas ao projeto "Re(vi)vendo Êxodos" (com duração de vários dias e percursos de centenas de quilômetros) teve, obviamente, cunho distinto. Antes de tudo, porque foram abarcadas em um projeto educacional no qual participaram alunos e alunas adolescentes, orientados por professores. Planejada, cada caminhada esteve cercada de 
controles: dias e horários de partida e de chegada, definição prévia de pontos de parada e pouso, extensa programação de tarefas a cumprir no trajeto. Antecedidas por numerosos preparativos, nelas ninguém rumou ao completo desconhecido, muito menos realizou uma premente travessia para escapar da morte. Para a escola promotora, as parcerias se revelaram essenciais, primeiramente em decorrência dos riscos e dificuldades implicados em uma iniciativa como essa, cujos participantes, na sua maioria, além de afeitos a hábitos citadinos, não haviam atingido a idade adulta. Daí o apoio do Exército, do Corpo de Bombeiros, da Polícia Militar e da Polícia Ambiental11. Com a consolidação dessa atividade, no projeto, bem como dos eixos temáticos orientadores (identidade, patrimônio e meio ambiente), as parcerias passaram a englobar outras instâncias públicas e entidades, como o Iphan, o Instituto Chico Mendes e o Instituto Brasileiro do Meio Ambiente e dos Recursos Naturais Renováveis $(\text { Ibama })^{12}$.

Contudo, seria enganador pensar a atividade de caminhada, no âmbito do projeto "Re(vi)vendo Êxodos", apenas como variação de um "estudo do meio" (prática bastante difundida, há algumas décadas, no âmbito escolar brasileiro). Pois se procurou também o contato com a dureza das caminhadas, em horas de percurso penoso, sob o sol e sem paradas acolhedoras próximas. Diferentemente do que ocorreu nas caminhadas registradas no projeto "Êxodos", essa dureza foi entendida como um componente desejável e relevante no processo formativo visado. Os desafios impostos ao corpo e as exigências atitudinais que implicavam foram considerados instrumentos de aprendizagens várias. Afinal, o que podem o corpo e a vontade fora dos limites urbanos, na ausência da familiaridade de paisagens, hábitos e costumes, em meio às vastidões do Cerrado?

\footnotetext{
${ }^{11}$ Veja-se que, já na primeira caminhada, que envolveu 48 alunos, foram estabelecidas parcerias com o Grupo Escoteiro João de Barro, o Corpo de Bombeiros Militar do DF, a Polícia Militar Ambiental em Candangolândia e o Exército, além de uma parceria com a equipe do Roteiro Ecoturístico Missão Cruls (então vinculado ao mandato de um deputado da Câmara do Distrito Federal), sem contar outros contatos necessários para os pousos no percurso (BAPTISTA, 2019, p. 69).

12 Posteriormente, também outras escolas públicas se integraram ao projeto.
} 
Doze anos após a primeira caminhada, a "Revista Caminhos - o melhor do Brasil" sintetizou os objetivos da atividade:

A CAMINHADA é uma ação pedagógica, realizada desde 2004, que visa um profundo mergulho cultural, intelectual, emocional e físico dos alunos e participantes na região que pesquisaram ao longo do ano, dentro do Projeto. [...] visa aproximá-lo da diversidade cultural dessas populações, sua organização social, seu cotidiano e suas manifestações artísticas e culturais. (DOSSIÊ, 2016, p. 22) (13 $^{13}$

A noção de "mergulho" já havia sido salientada pelo professor Luís Guilherme Baptista, em 2009:

Nós não passeamos, nós mergulhamos. Então, é necessário um envolvimento profundo dessas crianças, desses jovens, com a proposta. É necessário levantar às seis da manhã, estar pronto às sete horas; começar a caminhar às sete e meia e andar de quatro a cinco horas por dia; estar pronto para assistir aula à tarde e com a comunidade, à noite. [...] é aula, tudo é aula. Os alunos têm contato com a comunidade à noite para aprender artesanato, para aprender o modo de vida deles, para aprender como se faz garapa, para aprender como se vive, como é que se pensa, como se dança, como se cria nessas regiões. Então, eles vão sendo envolvidos em tudo e não se trata apenas de observar. Tem apresentação de congada, de jongo e eles participam, têm de dançar e se interessar, pesquisar e escrever. (BAPTISTA, 2012, p. 179)

Em vez de observar a distância, convém imergir em práticas, saberes e teias de sociabilidade, mesmo que temporariamente. Ainda aqui pode ser vislumbrada uma inspiração no trabalho de Sebastião Salgado, se considerado o contato estreito que o fotógrafo estabelece, em seus projetos, com os grupos humanos que fotografa.

Nas caminhadas, sempre foi previsto muito a reconhecer (dados os estudos prévios) e a descobrir: outros fazeres, outras formas de viver, não tão distantes geograficamente. Pois os percursos foram traçados, na maior parte das vezes, tendo em conta áreas próximas a Brasília: Brazlândia a Planaltina, 7 dias, 110 km a pé, em 2004; no ano seguinte, Morro da Serra dos Pireneus ao Catetinho, em Brasília, 16 dias, 280 km a pé; em 2006, do Marco Zero da Missão Cruls, em

\footnotetext{
13 "Órgão máximo de divulgação", a revista é outra frente de expressão criativa aberta pelo “Re(vi)vendo Êxodos". Lançada em 2016, em seu número "O” se indicava a intenção de nela "memoriar o projeto e suas atividades" (QUEM, 2016, p. 7).
} 
Formosa, ao Parque Nacional de Brasília, 14 dias e $310 \mathrm{~km}$ a pé... E outras caminhadas se sucederam (Iphan, 2015, p. 75). A história e a geografia dessas áreas, pesquisadas ao longo do ano letivo, foram confrontadas com as vivências do caminho: o contato direto com o relevo, a vegetação e os cursos d'água; a interação com moradores, da qual resultou a escuta de seus "causos" e relatos de vida, memórias de outros tempos e ponderações sobre o presente; a vivência, ainda que breve, de diferentes mundos do trabalho, assim como dos momentos de confraternização festiva (BAPTISTA, 2012, p. 179).

Os longos trajetos a pé do projeto "Re(vi)vendo Êxodos", pontuados por desafios, com altas exigências pessoais, são apostas na transformação dos caminhantes. Agendada para o término de um ano letivo repleto de atividades associadas ao projeto, cada caminhada não deixa de compor um dos muitos ritos de instituição desses jovens em adultos ${ }^{14}$.

Essa transformação envolve também repensar o lugar de Brasília em relação às localidades de seu entorno. Estabelecer laços com algo que o projeto moderno deixou à sombra - as cidades e as povoações que existiam muito antes da construção de uma nova capital federal, juntamente com seus habitantes e seus modos de viver, muitos deles carregados de tradições geralmente identificadas com “atraso”. Memórias e histórias que pareciam não importar; práticas populares e vidas aparentemente destituídas da distinção das lembranças. Ensaiando uma inversão do movimento costumeiro das pequenas cidades para as metrópoles, as caminhadas do projeto "Re(vi)vendo Êxodos" deixaram Brasília para privilegiar e valorizar, em seu roteiro, localidades como Brazlândia, Planaltina, Formosa, Goianésia, Cristalina...

\footnotetext{
${ }^{14}$ A expressão "ritos de instituição" remete a Pierre Bourdieu, que a propôs como contraponto crítico a "ritos de passagem", de modo a assinalar uma forma de produção social da diferença. Conforme Bourdieu: "ao marcar solenemente a passagem de uma linha que instaura uma divisão fundamental da ordem social, o rito chama a atenção do observador para a passagem (daí a expressão rito de passagem) quando, na verdade, o que importa é a linha. [...] instituir é consagrar, ou seja, sancionar e santificar um estado de coisas, uma ordem estabelecida [...] a investidura (do cavaleiro, do deputado, do presidente da República etc.) consiste em sancionar e em santificar uma diferença (preexistente ou não), fazendo-a conhecer e reconhecer, fazendo-a existir enquanto diferença social, conhecida e reconhecida pelo agente investido e pelos demais" (BOURDIEU, 1998, p. 98-99, grifo do autor).
} 
Participante pela primeira vez de uma dessas caminhadas em 2006, quando cursava o Ensino Médio, e que em 2015, então estudante universitário, se mantinha vinculado ao projeto, Rodrigo da Silva Soares destacou algumas dimensões da sua experiência pessoal:

É como se abrisse um leque de visão. Um olhar ampliado das coisas. Reconhecer o que é Brasília e o que está além, nos arredores, dar valor à importância do local em que vivo. Aqui, na área urbana, não temos contato com a cultura popular que nos rodeia. A ação nos permite dar uma pausa da rotina, do urbano, para entender o Brasil, os vários 'Brasis' que existem por aí (IPHAN, 2015, p. 72$)^{15}$.

“Tudo é aula”, e em cada encontro há algo a ensinar e a aprender - com as falas, as memórias, os gestos, os sabores. Yuri Soares, ex-participante do projeto que veio a se tornar professor de História, em 2018 relatou um episódio de sua experiência de caminhada:

Um dos pontos mais marcantes do trajeto foi a visita ao Centro de Tradições Populares, mais conhecido como Boi de Seu Teodoro, em Sobradinho, onde o saudoso mestre Teodoro Freire falou sobre folclore, lembrou da juventude no Maranhão, da migração para Brasília e de seu trabalho na UnB. Após um longo dia de trajeto por ruas de terra, matas, conversas e um típico jantar brasileiro que mesclava tradições culinárias do Maranhão e do Centro-Oeste, nós fomos agraciados com uma belíssima festa com a comunidade (SOARES, 2018, p. 58) ${ }^{16}$.

De forma ambiciosa, em 2008 foi feita uma grande viagem, parte a pé, parte com uso de ônibus: como forma de comemorar o centenário de nascimento de Guimarães Rosa, o percurso abarcou localidades de Minas Gerais e de Goiás, nas veredas roseanas entre Arinos, Morrinhos, Urucuia, Riachinho, Sagarana, Buritis, Cabeceiras e Unaí. A esse respeito, a professora Marilene Lara Carvalho registrou, em 2020, uma lembrança particularmente vívida, na qual se uniram literatura, arquitetura, música, calor humano e luz do luar:

Perto de Buritis, num assentamento do MST, eu e a professora Mary demos uma aula memorável dentro de uma Igreja, onde não havia nem banco para sentar, mas estava repleta de pessoas

\footnotetext{
15 Três das nove imagens fotográficas contidas neste artigo são de Rodrigo Soares.

16 Vê-se que o tema das migrações continuou presente nas caminhadas nos momentos de encontro com os moradores das paragens, vislumbrado, no exemplo dado, de forma positiva.
} 
atentas. Levamos todo o equipamento e acabamos a aula com o final do livro de João Guimarães Rosa, Grande Sertão Veredas: Riobaldo, diante do corpo de Diadorim, diz: Este é o amor encantado, que vai seguir comigo a minha vida inteira...

No final da aula, ao som de Luar do Sertão, na voz de Milton Nascimento... ao sair da igreja, tinha uma lua de todo tamanho, como recompensa. Era de encher, não só o céu, mas também os olhos e consequentemente a alma (CARVALHO, 2020).

Pode-se afirmar que as caminhadas passaram a definir um novo núcleo de registros fotográficos, que, embora tendo por referentes os muitos encontros e contatos do caminho, apresentam os caminhantes como protagonistas. São, sobretudo, suas vivências que pautam as imagens das caminhadas: momentos de cansaço, percalços, agruras, tristezas, mas também de descanso, consolo, alegria, solidariedade e companheirismo, de escuta e de fala. Nas imagens, pulsa a urgência de documentar, principalmente o grupo - seja na foto posada, como aquela sob o Chapéu do Sol (Imagem 4), seja no alívio do calor e no regozijo coletivo provocado pela água que jorra do carro-pipa (Imagem 5), seja ainda nas paradas em que as atividades se assemelham às aulas formais (Imagens 6 e 7).

Imagem 4 - Caminhada de 2017, município de Cristalina, Goiás: pesquisa na área da Pedra Chapéu do Sol. Pausa para o registro fotográfico a ser posteriormente compartilhado. Foto de autoria de Rodrigo Soares.

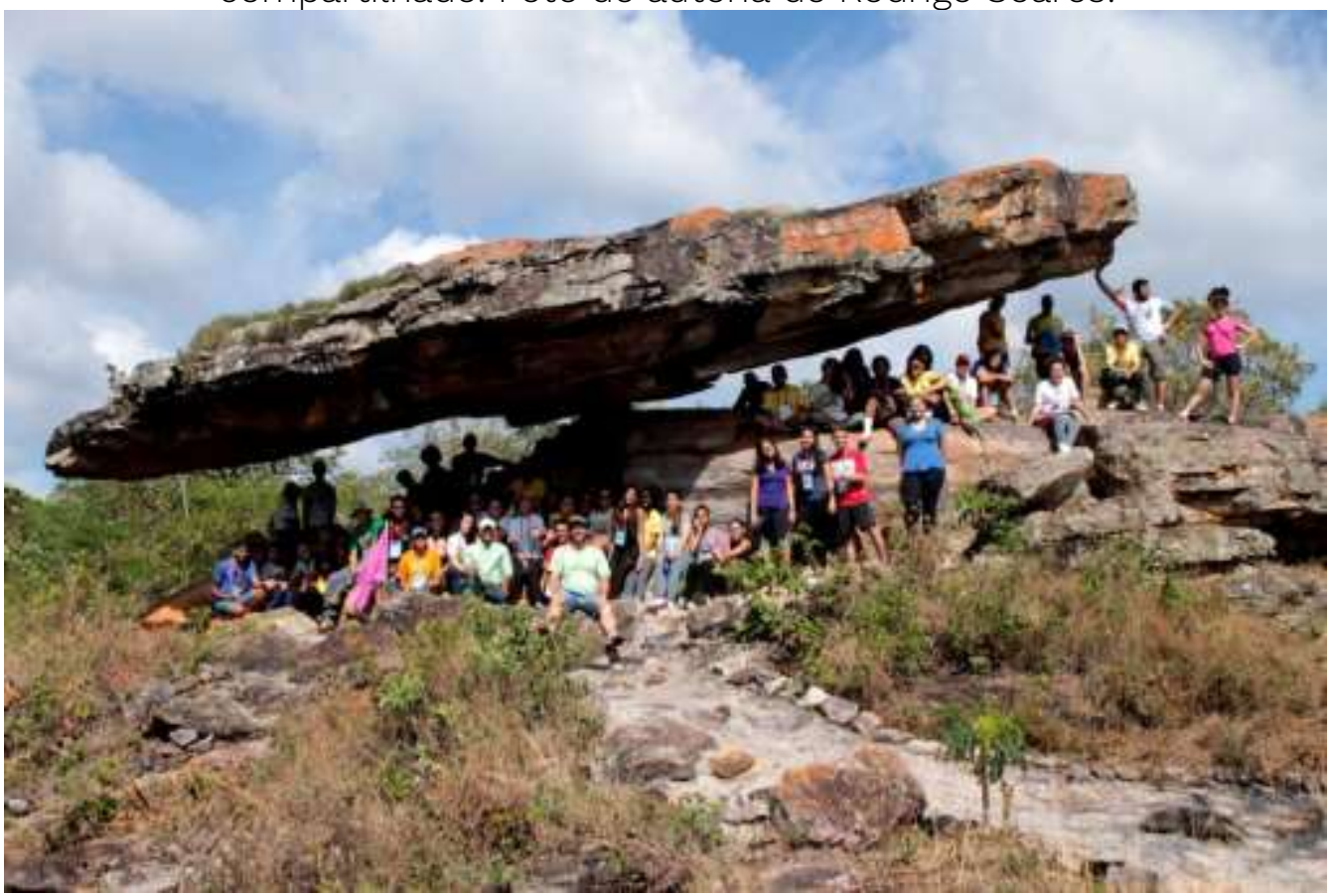

Fonte: acervo do projeto "Re(vi)vendo Êxodos". 
Imagem 5 - Caminhada de 2017, município de Luziânia, Goiás: alunos tomam banho com a água que jorra do carro-pipa, após chegada em pouso. Foto de autoria de Rodrigo Soares.

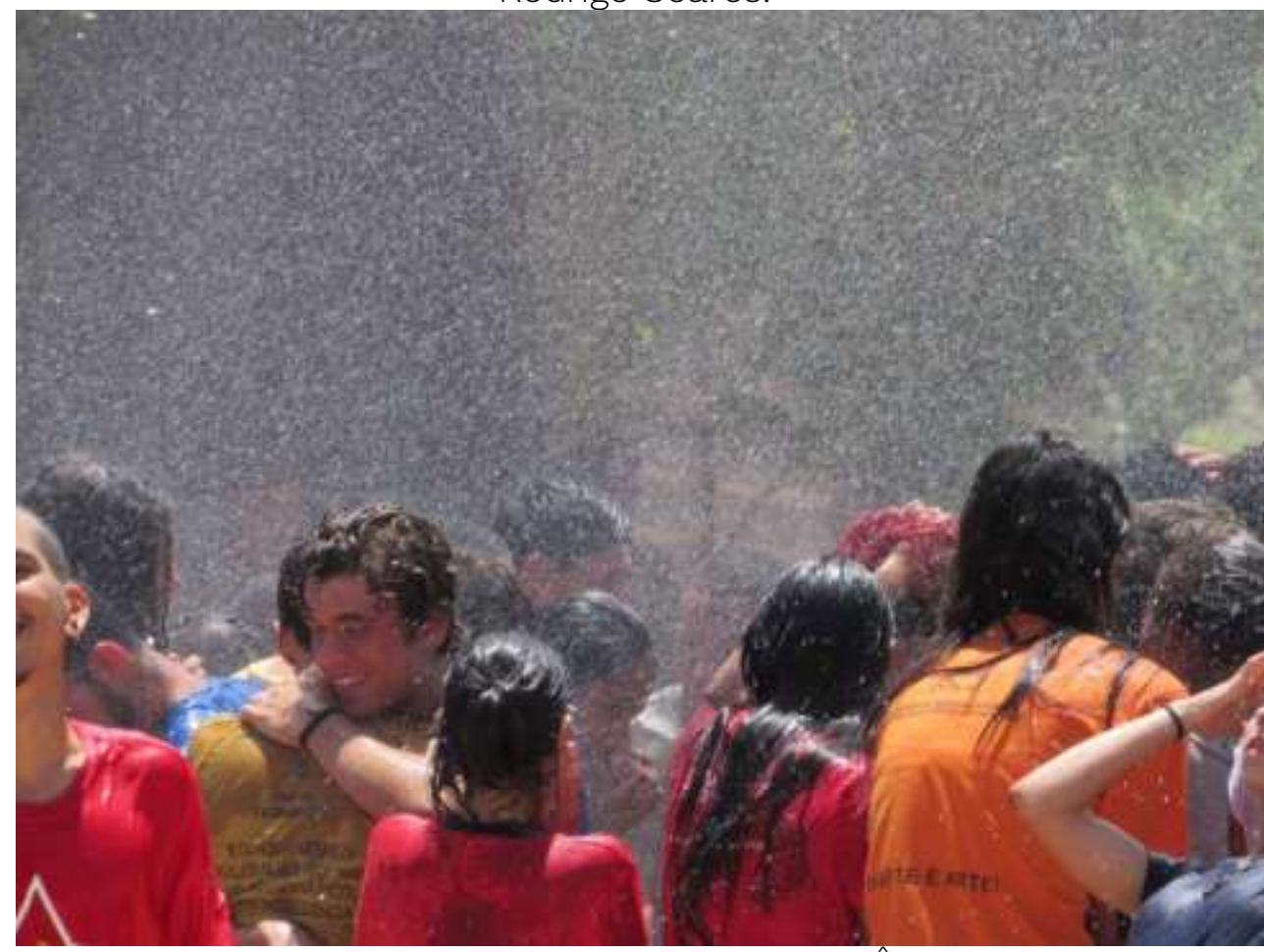

Fonte: acervo do projeto "Re(vi)vendo Êxodos".

Imagem 6 - Caminhada de 2017, Reserva Particular do Patrimônio Natural Linda Serra dos Topázios, município de Cristalina, Goiás: aula no pouso, com o jornalista e ambientalista Jaime Sautchuk, falecido em 14 de julho de 2021. Foto de autoria de Rodrigo Soares.

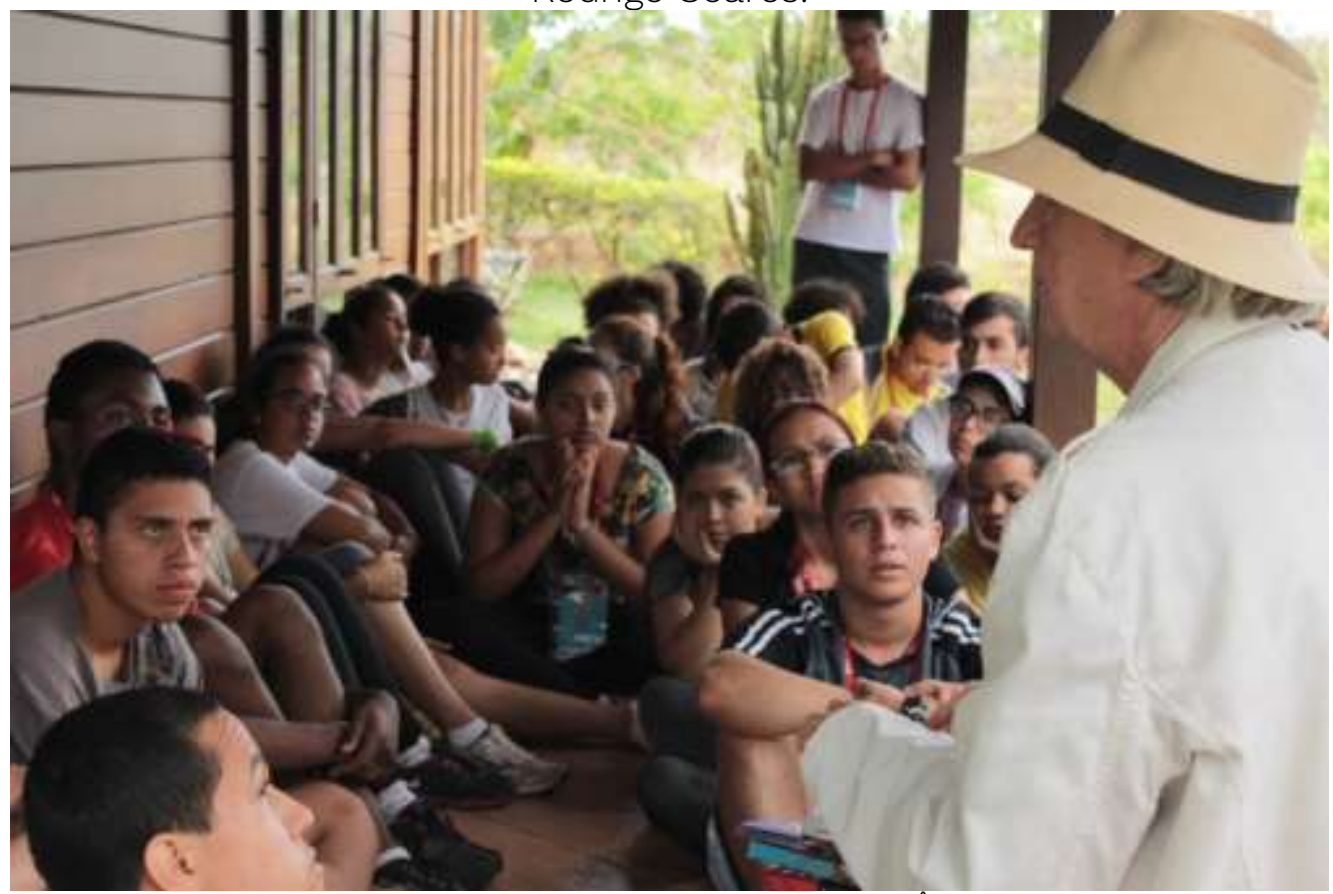

Fonte: acervo do projeto "Re(vi)vendo Êxodos". 
Imagem 7 - Caminhada de 2016, Natinópolis, Goiás: aula noturna. Foto de autoria de Fontenelle Moraes.

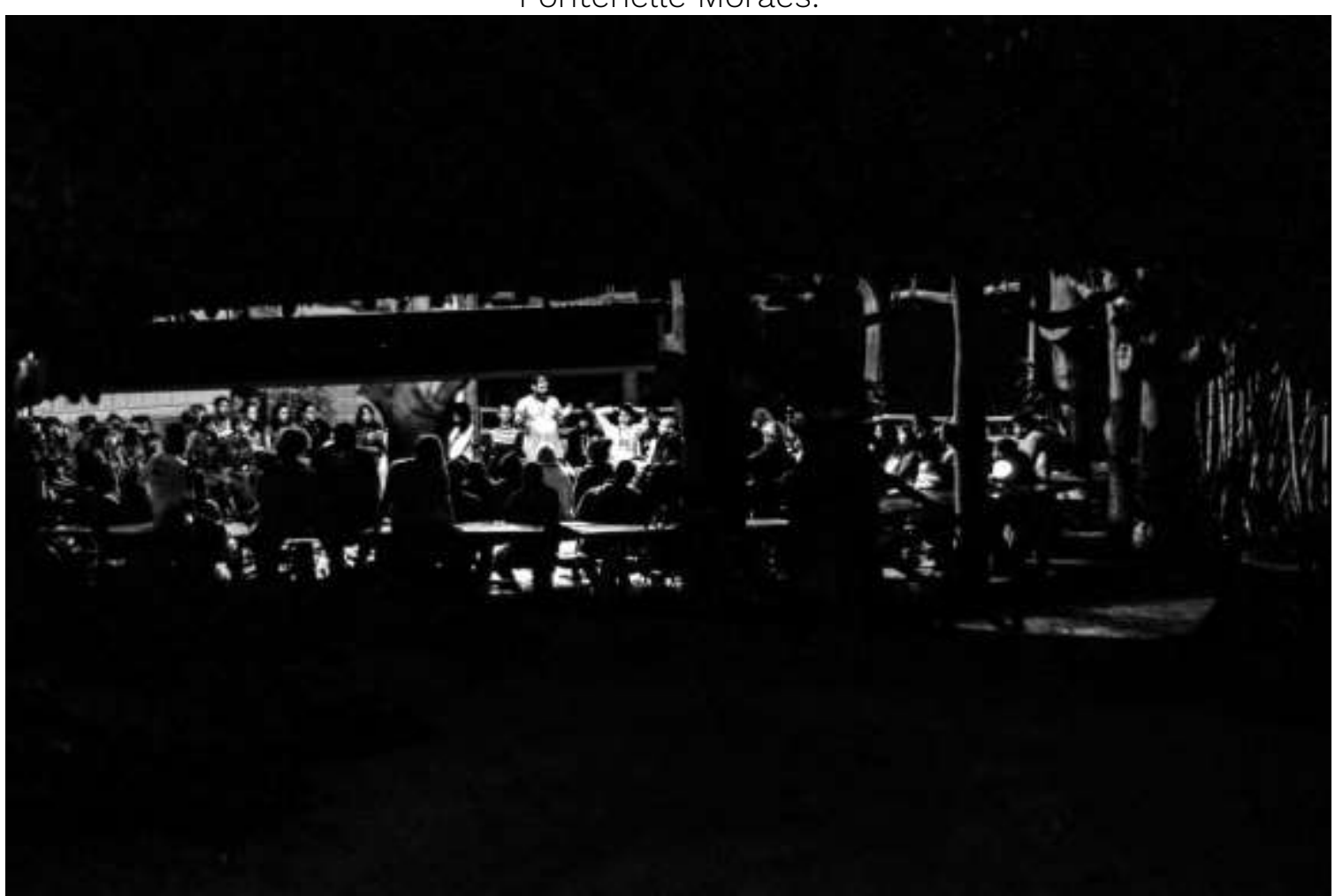

Fonte: acervo do projeto "Re(vi)vendo Êxodos".

Chama a atenção, nas imagens 6 e 7, o peso da presença dos alunos na composição. Na imagem 6, o jornalista Jaime Sautchuk, de costas e em primeiro plano, serve de "trampolim" para que o olhar salte para os rostos dos caminhantes atentos. Na imagem 7, embora a área mais clara seja aquela que atraia o olhar e, por consequência, destaque o professor (que tem a fala), o jogo de luz e sombra, bem como o enquadramento, reforçam o eixo horizontal central, remetendo mais a uma situação de assembleia do que à tradicional configuração de uma sala de aula. 
Imagem 8 - Caminhada de 2016, município de Goianésia, Goiás. Os caminhantes apinham-se e seguem pela estrada em curva, em meio à amplitude da paisagem. Foto de autoria de Fontenelle Moraes.

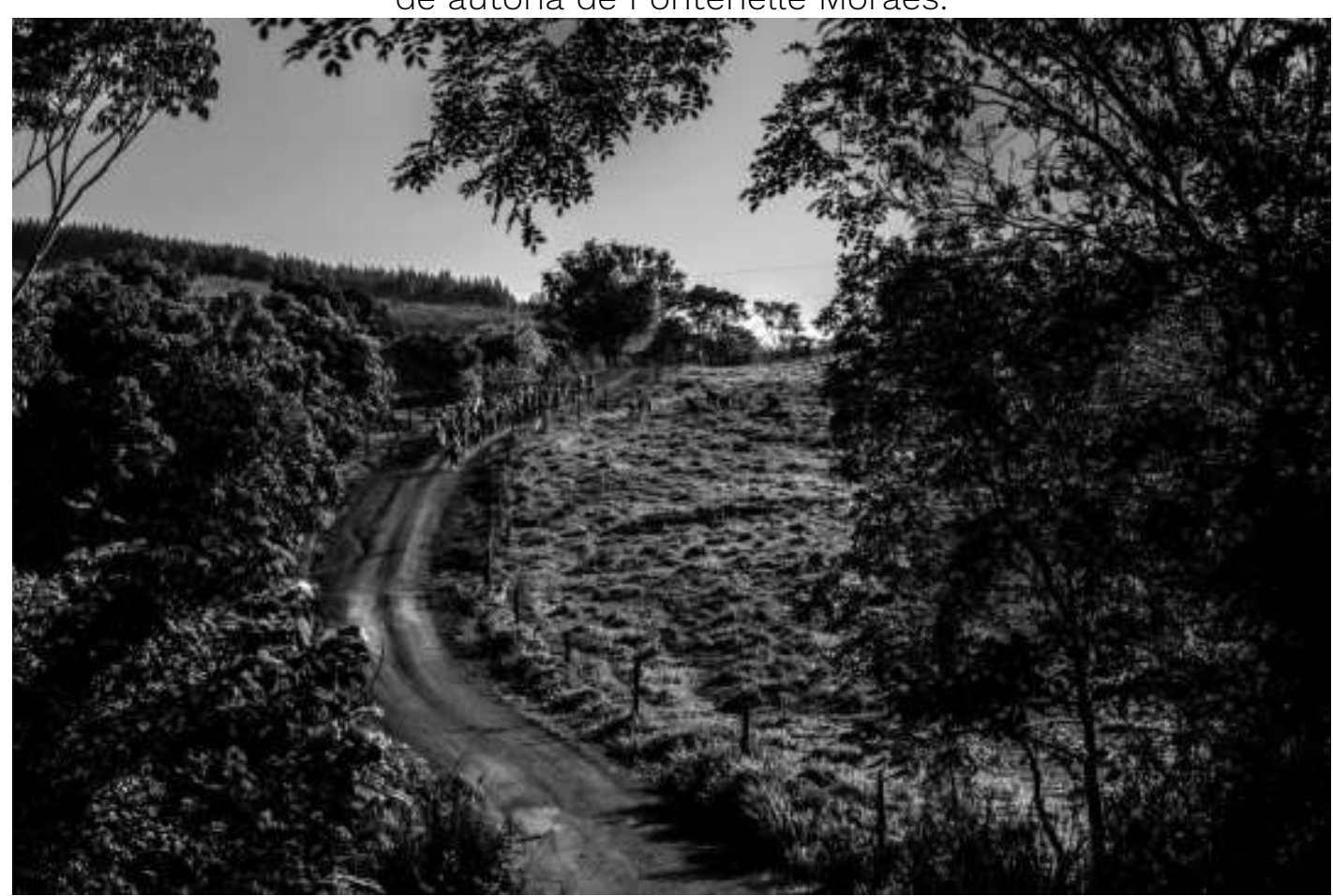

Fonte: acervo do projeto "Re(vi)vendo Êxodos".

Na imagem 8, não obstante a vegetação ocupar a maior parte do quadro, as árvores em primeiro plano oferecem a moldura para o tema principal, ou seja, os caminhantes (o que é reforçado pelos ramos que pendem na área superior, ao centro, apontando para eles). Sua pequenez em meio à amplidão da paisagem acaba por acentuar o sentido quase épico da tarefa que cumprem: sua distribuição compacta no espaço (e no quadro fotográfico) sugere união.

Reconhecido pelo Iphan, o projeto "Re(vi)vendo Êxodos" se mostra afinado com a reconfiguração das políticas de memória articuladas às ações de preservação do patrimônio cultural brasileiro, em especial a partir da Constituição Federal de 1988. Políticas que vêm se pautando por narrativas e ações mais inclusivas e que, quanto ao chamado "patrimônio imaterial", priorizaram, a partir dos anos 2000, a valorização e o registro de práticas culturais de grupos até então postos à margem da maior parte das ações de preservação, como povos indígenas, grupos afrodescendentes e comunidades tradicionais. Houve, ainda, a remodelação de metodologias de inventário e seleção de bens culturais, de modo a explicitar a necessidade de perspectivas colaborativas, que 
implicassem, em relação aos detentores do patrimônio cultural, aproximação, escuta, compartilhamento e corresponsabilidade. Tais mudanças também têm reverberado em ações de "educação patrimonial" que, renovadas, valorizam o trabalho de campo e o contato direto com manifestações culturais e seus detentores, abrindo-se a experiências cognitivas, afetivas e sensoriais, como se pressente no registro da vista noturna da Capela de São João Batista Menino, em Pirenópolis, na imagem 9.

Imagem 9 - Capela de São João Batista Menino, município de Pirenópolis, Goiás. O local é visitado e pesquisado pelos alunos que participam do "Re(vi)vendo Êxodos" há 15 anos, com base em proposta de ação educativa voltada para o patrimônio cultural criada por Tadeu Gonçalves, parceiro e apoiador do projeto. Foto de autoria de Fontenelle Moraes.

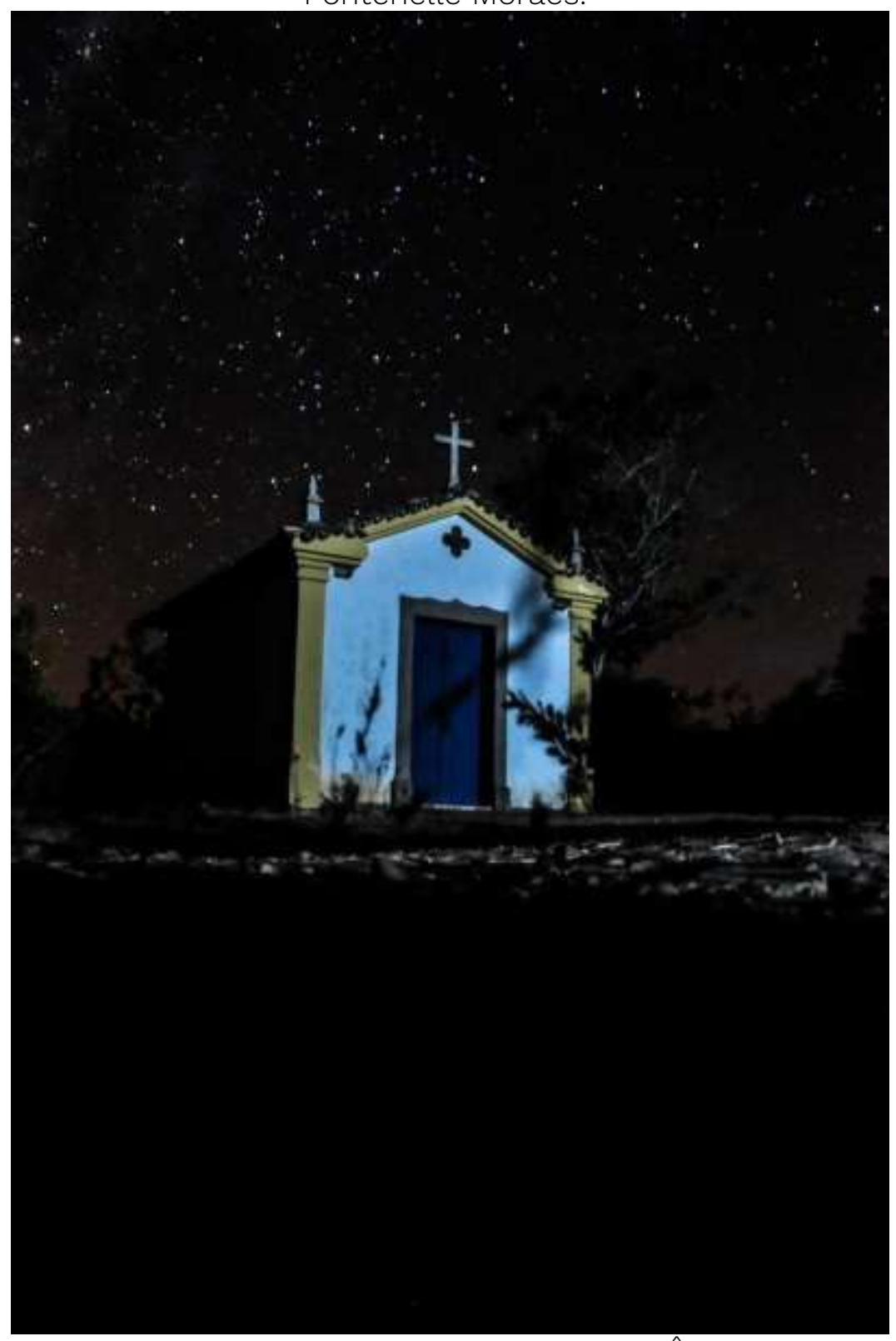

Fonte: acervo do projeto "Re(vi)vendo Êxodos". 
Considerando-se que as nove imagens aqui destacadas foram produzidas por participantes do projeto (ex-alunos tornados monitores), nota-se que se apresentam como indícios dos significados marcantes dessa experiência em suas vidas.

\section{Para lidar com a catástrofe}

O mundo compartilha, atualmente, embora de forma intensamente desigual, os efeitos de sua mais recente catástrofe, que se apresentou como pandemia de COVID-19. Por sua extensão e profundidade, ela deverá marcar nossas considerações sobre o tempo presente, talvez vindo a refundá-lo. Como destacou Henry Rousso, a fugacidade do tempo presente lhe confere uma origem provisória, que a partir do século XX parece encontrar sua inteligibilidade nos “momentos mais mortíferos do passado próximo” e que, por essa mesma razão, costumam ser mais ativos na memória coletiva (ROUSSO, 2016, p. 26-27).

Em momento em que somos impelidos a ficar confinados em nossos lares e evitar, o mais possível, contatos presenciais demorados e intensos, por que, justamente, dar atenção a atividades que envolvem a saída de pessoas às ruas, não só para fotografar como para interagir com outras? Por que se ocupar de pessoas que, sem obrigação ou necessidade, escolhem caminhar longas horas em grupo, entrecruzando povoações e pequenas cidades?

Muitas são as camadas suscetíveis de análise contidas nessa ação educativa denominada "Re(vi)vendo Êxodos", persistentemente continuada; retenho e ressalto apenas alguns aspectos que podem justificar a reflexão sobre ela, neste momento. Trata-se de um projeto que aponta muito fortemente para o sentido do coletivo, da escuta, da partilha, da solidariedade e do engajamento. Seus participantes conhecem e reconhecem grande variedade de paisagens, práticas culturais e pessoas, sendo sensibilizados e afetados por fazeres e dizeres. No próprio processo de participação, produzem registros que vão conformar a memória de suas experiências, e que, sendo significativas (como indicam os relatos e as imagens fotográficas dos participantes anteriormente destacados), alimentarão suas trajetórias de vida. 
Caminhante contumaz, Francesco Careri considerou que "o percurso mais breve nunca é o melhor" - sempre há muito para ver (e viver). Para o arquiteto italiano, "a qualidade do tempo da travessia depende também das atividades que podem preenchê-lo" (CARERI, 2017, p. 70) e "perdendo tempo ganha-se espaço" (CARERI, 2017, p. 87). Por que "perder tempo" percorrendo a pé um caminho que poderia ser feito por meio de ônibus ou de automóvel? Trata-se de uma das apostas do "Re(vi)vendo Êxodos": a caminhada mostra e ensina mais, uma vez que põe em contato, mobiliza sentidos e, assim, transforma. Induz a memórias incorporadas - a paisagem vista na fotografia é distinta da que é palmilhada. E gera memórias compartilhadas, a partir de encontros e descobertas. É projeto, ação e metáfora de transformação ${ }^{17}$.

Dar destaque a essa ação formativa permite alertar que, mesmo em cenários de extremo sofrimento, dor e desolação, a esperança pode sobrevi(ve)r. Os adolescentes de uma escola pública de Brasília souberam transformar em algo seu, em outros tantos caminhos, centelhas de esperança entrevistas nas fotografias de Sebastião Salgado (e vislumbradas por Salgado em quem ele fotografou). A esperança põe em movimento.

Por fim, se o caminhar, neste momento, não pode ser tão livre como desejaríamos, cabe pensar que essa condição é provisória, apesar de sua duração ter extrapolado até mesmo previsões pessimistas. Caminhadas, todavia, nunca são contínuas: é preciso parar, repor energias, rever o roteiro, juntar forças. Só então é possível retomar as ruas e os caminhos, agindo e criando.

\footnotetext{
17 Nisso é possível estabelecer outro elo com Sebastião Salgado: Paulo Maia (2017) vê no que denomina "sentimento de travessia" um nexo importante do trabalho do fotógrafo.
} 


\section{Referências}

A SECRETARIA de Cultura divulga o resultado oficial do $V$ Prêmio José Aparecido de Oliveira. In: SECRETARIA DE CULTURA DO DISTRITO FEDERAL, Brasília, 5 dez. 2012. Disponível em: http://www.cultura.df.gov.br/a-secretariade-cultura-divulga-o-resultado-oficial-do-v-premio-jose-aparecido-de-oliveira/. Acesso em: 13 mar. 2021.

ACOSTA SIERRA, Paola Helena. Justicia [poética] y memoria [inquietante]. Bogotá: Universidad Pedagogica Nacional, 2019.

BAPTISTA, Luís Guilherme. Memória: capítulo 1, 2001. Revista Caminhos - o melhor do Brasil, Brasília, n. 1, p. 50-51, maio 2017. Disponível em:

https://issuu.com/revistacaminhos/docs/edicao1. Acesso em: 23 fev. 2021.

BAPTISTA, Luís Guilherme. Memória. Revista Caminhos - o melhor do Brasil, Brasília, n. 3, p. 68-69, dez. 2019. Disponível em:

https://issuu.com/revistacaminhos/docs/edicao3. Acesso em: 23 fev. 2021.

BAPTISTA, Luís Guilherme. Memórias 2002-2003. Revista Caminhos - o melhor do Brasil, Brasília, n. 2, p. 59-60, jun. 2018. Disponível em:

https://issuu.com/revistacaminhos/docs/edicao2. Acesso em: 23 fev. 2021.

BAPTISTA, Luís Guilherme. Projeto Re(vi)vendo Êxodos: uma vivência em patrimônio, identidade e meio ambiente na escola pública. In: FÓRUM NACIONAL DO PATRIMÔNIO CULTURAL, 1., 2009, Ouro Preto. Anais [...]. Brasília: Iphan, 2012. v. 2. p. 173-179. Sistema Nacional de Patrimônio Cultural - desafios, estratégias e experiências para uma nova gestão

BENJAMIN, Walter. A imagem de Proust [1929]. In: BENJAMIN, Walter. Magia e técnica, arte e política: ensaios sobre literatura e história da cultura. São Paulo: Brasiliense, 1985. (Obras escolhidas, v. 1). p. 36-49.

BERGER, John. Para entender uma fotografia. In: BERGER, John. Para entender uma fotografia. Introd. e org. Geoff Dyer. São Paulo: Companhia das Letras, 2017a. p. 36-41.

BERGER, John. Uma tragédia do tamanho do planeta - conversa com Sebastião Salgado. In: BERGER, John. Para entender uma fotografia. Introd. e org. Geoff Dyer. São Paulo: Companhia das Letras, 2017b. p. 207-215.

BOURDIEU, Pierre. Os ritos de instituição. In: BOURDIEU, Pierre. A economia das trocas linguísticas: o que falar quer dizer. São Paulo: Edusp, 1998. p. 97-106.

CARERI, Francesco. Caminhar e parar. São Paulo: Gustavo Gili, 2017.

CARVALHO, Marilene Lara. Memória - Casulo de caminhantes. Revista

Caminhos - o melhor do Brasil, Brasília, n. 4, 2020. Disponível em: 
https://www.revistacaminhos.org/memoria-casulo-de-caminhantes.html. Acesso em: 23 fev. 2021.

DOSSIÊ Caminhada 2016 - Cristal-Tradição-Resistência. Revista Caminhos - o melhor do Brasil, Brasília, n. 0, p. 22-39, nov. 2016. Disponível em: https://issuu.com/revistacaminhos/docs/edicao0. Acesso em: 23 fev. 2021.

EL ATAQUE contra la AMIA: memoria activa deja la plaza Lavalle: considera agotado el reclamo callejero. La Nación, 28 dic. 2004. Disponível em: https://www.lanacion.com.ar/sociedad/memoria-activa-deja-la-plaza-lavallenid666682/ Acesso em: 15 mar. 2021.

GALARD, Jean. Beleza exorbitante: reflexões sobre o abuso estético. São Paulo: Ed. Fap-Unifesp, 2012.

GONÇALVES, Janice. Além da superfície: memória da dor, materialidade e patrimônio cultural. In: FRAGA, Hilda Jaqueline; SCHIAVON, Carmen G. B.; GASTAUD, Carla R. (org.). Patrimônio no plural: práticas e perspectivas investigativas. Porto Alegre: Selbach \& Autores Associados, 2018. p. 77-94.

HUYSSEN, Andreas. A cultura da memória em um impasse: memoriais em Berlim e Nova York. In: HUYSSEN, Andreas. Culturas do passado-presente: modernismos, artes visuais, políticas da memória. Rio de Janeiro: Contraponto: Museu de Arte do Rio, 2014a. p. 139-153.

HUYSSEN, Andreas. O teatro de sombras como veículo da memória em William Kentridge e Nalini Malani. In: HUYSSEN, Andreas. Culturas do passado-presente: modernismos, artes visuais, políticas da memória. Rio de Janeiro: Contraponto: Museu de Arte do Rio, 2014b. p. 57-82.

IPHAN. Prêmio Rodrigo Melo Franco de Andrade - 28a edição. Brasília: Iphan, 2015. Disponível em: https://www.gov.br/iphan/pt-br/acoes-eprogramas/premios/premio-rodrigo-melo-franco-de-andrade1/REVISTA_PRMFA_2015.pdf. Acesso em: 23 fev. 2021.

KURY, Mário da Gama. Apresentação. In: ARISTÓTELES. Política. 3. ed. Trad., introd. e notas Mário da Gama Kury. Brasília: Ed. da UnB, 1997. p. 5-12.

LE GOFF, Jacques. Documento/monumento. In: LE GOFF, Jacques. História e memória. 4. ed. Campinas, SP: Ed. da UNICAMP, 1996. p. 535-553.

MAIA, Paulo. Olhar, memória, imaginário em Sebastião Salgado. Scriptorium, Porto Alegre, v. 3, n. 2, p. 192-202, jul./dez. 2017. Disponível em: https://revistaseletronicas.pucrs.br/index.php/scriptorium/article/download/291 80/16721/. Acesso em: 22 fev. 2021.

MELENDI, Maria Angélica. Antimonumentos: estratégias da memória (e da arte) numa era das catástrofes. In: SELIGMANN-SILVA, Márcio (org.). Palavra e imagem, memória e escritura. Chapecó: Argos, 2006. p. 227-245. 
PARQUE de la Memoria. In: PARQUE DE LA MEMORIA. [Buenos Aires], 2021. Disponível em: https://parquedelamemoria.org.ar/. Acesso em: 15 mar. 2021.

QUAL a escola que queremos? - Prêmio Gestão Escolar 2012. In: FUNDAÇÃO SANTILLANA. Brasília: CONSED, 2012. Disponível em:

https://www.fundacaosantillana.org.br/wp-

content/uploads/2019/12/59_qual_escola_queremos.pdf. Acesso em: 15 mar. 2021.

QUEM somos. Revista Caminhos - o melhor do Brasil, Brasília, n. 0, p. 7, nov. 2016. Disponível em: https://issuu.com/revistacaminhos/docs/edicao0. Acesso em: 23 fev. 2021.

RE(VI)VENDO Êxodos recebe menção honrosa no IV Prêmio José Aparecido de Oliveira. In: EDUCAÇÃO PATRIMONIAL. [S.l.], 15 dez. 2011. Disponível em: http://educacaopatrimonial.wordpress.com/2011/12/15/revivendo-exodosrecebe-mencao-honrosa-no-iv-premio-jose-aparecido-de-oliveira/. Acesso em: 23 fev. 2021.

ROUSSO, Henry. A última catástrofe: a história, o presente, o contemporâneo. Rio de Janeiro: FGV Ed., 2016.

SALGADO, Sebastião. Êxodos. São Paulo: Companhia das Letras, 2000.

SALGADO, Sebastião; FRANCQ, Isabelle. Da minha terra à Terra. São Paulo: Paralela, 2014. E-book.

SOARES, Yuri. Uma catarse necessária. Revista Caminhos - o melhor do Brasil, Brasília, n. 2, p. 58-59, jun. 2018. Disponível em:

https://issuu.com/revistacaminhos/docs/edicao2. Acesso em: 23 fev. 2021.

SODARO, Amy. Exhibiting atrocity: memorial museums and the politics of past violence. New Brunswick: Rutgers University Press, 2018.

SODARO, Amy. Museus memoriais: a emergência de um novo modelo de museu. PerCursos, Florianópolis, v. 20, n. 44, p. 207-231, 2019. Disponível em: https://www.periodicos.udesc.br/index.php/percursos/article/view/19847246204 42019207/pdf. Acesso em: 28 fev. 2021.

SONTAG, Susan. Diante da dor dos outros. São Paulo: Companhia das Letras, 2003.

TAYLOR, Diana. O arquivo e o repertório: performance e memória cultural nas Américas. Belo Horizonte: Ed. UFMG, 2013.

VILLARREAL, Pollyanna. Exposição em Pirenópolis comemora 20 anos do Re(vi)vendo Êxodos. In: BSB CAPITAL. Brasília, 23 fev. 2020. Disponível em: https://www.bsbcapital.com.br/exposicao-em-pirenopolis-comemora-20-anosdo-revivendo-exodos/. Acesso em: 10 mar. 2021. 
Universidade do Estado de Santa Catarina - UDESC Programa de Pós-Graduação em História - PPGH Revista Tempo e Argumento Número Especial - 2021 tempoeargumento.faed@udesc.br 